\title{
Communities and Libraries in Times of Crisis: A Journey of Knowledge Inquiries in South Carolina
}

\author{
Feili Tu-Keefner \\ University of South Carolina
}

\begin{abstract}
In October 2015, several counties in South Carolina experienced catastrophic trophic flooding that caused severe damage. Using a framework for risk communication preparedness and implementation recommended by public health experts, this study investigated public libraries and their legitimacy as partners of public health agencies during and after a disaster. The results show that the libraries in the areas affected created disaster-recovery centers, illustrating their value in facilitating emergency response and recovery. However, the findings also show librarians were not fully prepared to provide disaster and health information, especially through online venues. Information and technology literacy issues created barriers for community members in accessing disaster health information and filing FEMA applications online. It is recommended that public libraries provide user-friendly, reliable disaster and health digital resources, making them available permanently, and updating the information consistently.
\end{abstract}

Keywords: disaster preparedness, health information, natural disasters, public Libraries

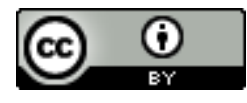

This is an Open Access article distributed under the terms of the Creative Commons Attribution 4.0 International License (http://creativecommons.org/licenses/by/4.0), which permits unrestricted use, distribution, and reproduction in any medium, provided the original work is properly cited. 


\section{Background}

South Carolina, a southern coastal state, is not a stranger to natural disasters such as hurricanes and flooding. According to data recorded by the National Oceanic and Atmospheric Administration's (NOAA, 2018) historical hurricane track, between 2010-2016, six major hurricanes, three in 2016 alone, had a direct impact on the state. However, the data did not include the disasters that occur frequently during hurricanes. An example is the catastrophic flooding, triggered by a cold front and Hurricane Joaquin in early October, 2015. This disastrous flood devastated several counties in South Carolina with its historic amount of rain. The NOAA categorized the rainfall and flooding as ranging "from anywhere between a 1-in-100 year event to a 1-in-1000 year event" (Di Liberto, 2015). The severe results of the flooding in 2015 included nineteen storm-related fatalities, more than 20,000 displaced community members (South Carolina Emergency Management Division, n.d.), loss of homes, and other calamities. Thirty-six counties were declared disasters. Parts of Richland, Orangeburg, and Clarendon counties in the central part of the state were extremely hard hit, including the city of Columbia, located in Richland County. However, the main campus of the University of South Carolina (UofSC) system, which is located in downtown Columbia, suffered only minor damage.

The School of Library and Information Science (SLIS) at UofSC is the only American Library Association (ALA)-accredited advanced degree program in the fields of library and information science (LIS) in South Carolina. In the immediate aftermath of the flooding, the research team received an internal grant from the University to conduct a situation-specific case study. The study investigated public libraries' value to their communities and their legitimacy as partners of public health agencies during and after a disaster. This included various aspects of information, technology, and user support.

\section{Public Library Services in the 2015 Flooding in South Carolina}


Libraries have long made valuable contributions to their communities, providing consistent, essential information services. Research findings show that public libraries, in times of crisis, are valuable sources and may aid in disaster preparedness, response, and recovery, as well as the provision of credible information. During the catastrophic flooding in South Carolina in October 2015, public librarians in several counties in the affected areas worked extensively with volunteers and responders to provide situation-specific and community-first information services. The U.S. Federal Emergency Management Agency (FEMA) dispatched agents to help with response and recovery in South Carolina before, during, and after the flood (Stapf, 2015). Once an area was declared a disaster, citizens could file claim forms with FEMA. Many FEMA agents were stationed at the local public libraries to work with community members.

\section{Knowledge Inquiries and Professional Responsibilities}

Librarians today play a significant role in improving the quality of life of the communities they serve through facilitating knowledge creation, preservation, and dissemination. LIS educators face the challenge of producing proficient future librarians and information professionals who will be strong advocates of providing innovative services to their communities. They are responsible for connecting students with real-world information activities, library services, and professional experiences. LIS researchers are well-positioned to investigate phenomena related to libraries and their social responsibilities and to integrate research findings that enhance curriculum development. It is essential to help LIS graduates become competent and confident professionals who can support their libraries' service to communities in times of crisis. The 2015 catastrophic flooding in South Carolina provided such a platform.

This funded research is a situation-specific case study examining the phenomena related to public libraries and their community engagement in a time of crisis. Our investigations center on public 
libraries' value to their communities, especially to vulnerable populations, and their legitimacy as partners of public health agencies during and after a disaster. The study included various aspects regarding information, technology, and user support. The targeted public libraries are the Richland Library (Richland Library, Richland County, South Carolina, 2019), the Orangeburg County Public Library system (Orangeburg County Library System), and the South Carolina State Library (South Carolina State Library, n.d.). A concomitant objective was to identify whether health science librarians took leadership roles in collaborating with public libraries for the provision of critical health information services to the community members during and after the disaster. Since the majority of the professional librarians participating in the study are SLIS alumni, we felt it was our responsibility to verify how well our graduates performed professionally during a crisis.

\section{The Design of This Case Study}

The concepts of action research were utilized to design this situation-specific case study. One of the study's goals was to show public libraries' legitimacy as partners of public health agencies. Therefore, the research design was based on a framework created by public health experts and used for risk communication preparedness and implementation regarding vulnerable populations in a pandemic flu setting. The methodology included focus-group meetings with public library administrators and librarians and an in-depth interview with a FEMA agent.

\section{Methodology and Data Collection}

\section{Public Libraries' Operations}

Focus group meetings with public library administrators and librarians were used to examine how libraries and librarians responded during this time. The participants were recruited through purposive sampling. They were library administrators and librarians from several locations specifically 
affected by flooding, i.e., the Richland Library Main Library and three of its branches, as well as the Orangeburg County Public Library system. Inclusion was limited to professional librarians who had earned a Master of Library and Information Sciences (M.L.I.S.) degree or equivalent. Other library personnel were identified and invited to participate because of their direct contributions in the library operations during and after the disaster. An exception was that one of the participants without an M.L.I.S. degree was invited because of that person's involvement in facility and information system management in the Richland Library Main Library and its branches.

\section{Public Libraries' Partnerships with Other Agencies}

A unique feature of this research design was the collection of qualitative data from a federal government emergency responder. Since FEMA centers were stationed in several public libraries, it was important for the research team to gather data about regarding FEMA agents' collaborations with public libraries. With the assistance of the Richland Library and the South Carolina State Library, the research team identified several FEMA agents for a possible interview. Then the researchers contacted the FEMA Office of External Affairs (https://www.fema.gov/office-external-affairs) to seek permission to interview them. Only one FEMA representative, who served as the site manager in South Carolina, was granted permission to meet with the research team. An in-depth interview with him was held to learn about issues regarding the agents' collaborations with the public libraries. He was also asked to comment on information-literacy challenges that he noticed among community members and the technology ability needed for community members to file damage claims.

\section{Results}

Our findings show how well public libraries provided situation-specific and community-first services during and after the flooding hit these local counties. 


\section{Public Libraries' Collaborations with Multiple Organizations and Their Legitimacy as Partners of Public Health Agencies}

A major goal of our inquiries was to investigate public libraries' legitimacy as partners of public health agencies and their value to the local communities during a disaster such as the 2015 South Carolina flooding. A secondary goal was to determine these libraries' legitimacy as partners of public health agencies. During and after the flood, public libraries collaborated with both the private and public sectors, including public health agencies, showing the magnitude of their involvement in facilitating emergency response and recovery (Tu-Keefner, Liu, Harnett, \& Hastings, 2017). The libraryadministrator participants discussed the success with which the public libraries had on a daily basis connected with and supported the work of a variety of public and private agencies (Tu-Keefner, Liu, Harnett, \& Hastings, 2017). The libraries also collaborated with local media sources to disseminate information to the general public. These public libraries were able to partner with other agencies to provide situation-specific information services and to satisfy the community-first information needs from patrons in responding to the flood (Tu-Keefner, 2016). The results clearly demonstrate the value of public libraries and their legitimacy as partners of public health agencies.

The Richland Library administrators and librarians successfully set up the disaster recovery centers for FEMA in their main library and branches by working with the offices of South Carolina State Senator Joel Lourie and U.S. Representative James E. Clyburn. Community members could easily meet with FEMA agents to seek federal aid and to access library services by visiting their local libraries. In fact, $14 \%$ of all FEMA applications were filed at the Richland Library's main and branch libraries. The library administrators, librarians, and the FEMA agent interviewed reported that the FEMA agents stationed at the public library disaster recovery centers were pleased with the facilities and support provided and felt satisfaction in working with librarians to help community members. Particularly, the 
FEMA agent expressed gratitude for the libraries' hospitality, clearly stating that public libraries are the perfect environment for serving as a post-disaster resource.

The local public libraries in the disaster areas also supported other public health agencies' operations, e.g., the South Carolina Department of Health and Environmental Control (DHEC), by providing space in the libraries to facilitate public health professionals' work on the ground. DHEC set up outside the libraries to provide water-testing kits and give tetanus shots after the flooding. The Richland Library was a water distribution site; in addition, librarians took books, toys, and computers to shelters. The successful collaborations with multiple and public health agencies show the value of public libraries and their legitimacy as partners of public health agencies in facilitating emergency response and recovery during crises.

\section{Critical Information Services Provided by Public Libraries}

In the professional literature, it is well-documented that people in crisis situations need access to accurate information and clear, specific instructions to help them act appropriately and make sound decisions (Tanner, Friedman, Koskan, \& Barr, 2009). The provision of credible information sources to users is a crucial service of public librarians in times of crisis, and this was clearly voiced by the librarian participants in this research. Our inquiries show that public libraries collaborated with local media sources to disseminate critical information to the community members regarding public health services, e.g., information regarding the availability of vaccines such as Tdap or tetanus. The librarians also responded to questions about water testing since many residents worried that flooding had contaminated water sources, and even disseminated information about scams and how to avoid them. In summary, before, during, and after the flood, public libraries and librarians teamed up with their partners (e.g., local media and government agencies) and successfully provided trustworthy, credible, community-first information to community members at a time when they were particularly vulnerable. 


\section{Uses of Technology and Social Media by Information Professionals}

Our findings show that technology access was crucial to obtaining credible information and disseminating resources and services to the community. The Internet was predominantly used by librarians to gather and distribute resources. Social media was widely used both by librarians to deliver information services and by community members to access information. In our analysis, the words Facebook and Twitter occurred more than any others, with the exception of FEMA. It was fortunate that the electricity stayed on, allowing Internet availability in many areas hit hard by flooding. Even though people might have been evacuated to shelters, they could use cell phones to access the Internet and social media. Therefore, it is recommended that libraries proactively create risk communication strategies in social media applications for effective information services.

\section{Concerns and Recommendations}

However, the results also revealed concerns that deserve the attention of libraries, librarians, and library and information science educators, so improvements may be made.

\section{Librarians' Competencies and Knowledge and Skills Required}

Although the public libraries and librarians performed well in response to this "thousand-year deluge"

(Di Liberto, 2015), this research shows that they had not been well-prepared in advance to identify, gather, distribute, and promote the use of disaster and health information. The following quote sums up the lessons that the participants of this study learned when the 2015 catastrophic flooding hit the local communities:

... it would be beneficial for us to start looking at ways to be prepared if this should ever happen again. And maybe looking at organizations that we could connect with now, so that if this should ever happen, we are better prepared to provide services and information." [Library Administrator/Librarian Subject \#13]

The public librarians in the study did not feel it necessary for LIS education programs to cover 
disaster preparedness, response, and recovery in the curricula. However, they think that continuing education (CE) is essential to better prepare librarians to provide disaster and health information services.

Recommendations. SLIS is well-positioned to create and deliver such types of interdisciplinary professional development resources. SLIS is one of the original creators of the UofSC Certificate of Graduate Study in Health Communication program, which has been available since 2009. This program is jointly administered by the Department of Health Promotion, Education, and Behavior at the Arnold School of Public Health and the Schools of Journalism and Mass Communications and Library and Information Science within the College of Information and Communications at UofSC. Therefore, the scholars and experts from these academic units are prepared to work together to create the content for the CE and professional development resources.

\section{Public Librarians' Use of Reliable Health Resources for Information Services}

Although the public librarians responded to the community members' information needs during and after the flooding, they had not been proactive in disseminating and promoting access to critical disaster information. The findings also show a discrepancy between the reliable resources vital to consumers and the health information shared with them by the public libraries (Tu-Keefner, Liu, Harnett, \& Hastings, 2017). For example, many credible health information resources, such as Medlineplus.gov and Ready.gov widely known and used by health information professionals, were not mentioned by the participants of the study. In fact, most of the public library administrators and librarians did not indicate that they had shared any specific health-related resources to community members online or in the libraries before, during, and after the disaster. In addition, minimal connections existed between public and health sciences libraries in the provision of health information services before, during, and after the disaster. Public librarians were not fully prepared to provide 
sufficient essential disaster and health information for adult users, especially through online venues, before during, and after the natural disasters hit South Carolina.

Recommendations. Based on our findings, we think that it important for public libraries to build capacity to serve the information needs of various types of users and diverse populations, including the general public of all ages, health professionals, and emergency responders and volunteers. The selection of appropriate disaster information resources in multiple languages for inclusion in library digital collections is crucial. It is recommended that public libraries provide reliable, user-friendly, multilingual disaster and health digital resources for both young and adult users, making them available permanently, and updating the information consistently.

Health sciences librarians can take on leadership roles in providing vital support to public librarians. Health sciences librarians are skilled at selecting and disseminating trustworthy health information and in using a variety of helpful resources for emergency and disaster preparedness and response. They can train public librarians in the use of National Library of Medicine (NLM) and National Network of Libraries of Medicine (NNLM) resources and in the delivery of effective health information services. To better serve the community's health information needs, we recommend that health sciences librarians team up with public librarians to deliver real-time health information services via social media.

\section{Community Members' Information and Technology Literacy Issues}

According to our findings, information and technology literacy issues created barriers for many community members in accessing FEMA applications and filing claims online. McKnight (2006) documented how local public libraries and librarians helped people affected by Hurricane Katrina file online FEMA claims in 2005. A decade later in South Carolina, the general public's lack of skill in using technology to access information remained a large problem. The FEMA agent who was interviewed 
described the difficulties community members had in accessing FEMA online claim forms and in understanding FEMA documentation. Our research results also show that public librarians worked extensively with the FEMA agents who were stationed in the disaster recovery centers in their libraries. The librarians were instrumental in helping community members cope with difficulties regarding technology access and understanding FEMA documentation.

Recommendations. Health sciences librarians can truly help general public users to access reliable electronic consumer health information. These librarians can also offer health-information literacy programs. We recommend that public libraries include user-friendly and easy-to-understand training materials on how to use online information related to disasters and health in their public libraries' digital collections described above. By promoting the use of such resources and services, community members can be helped to overcome information and technology literacy problems by simply clicking on links on the public libraries' websites anytime, anywhere. That could aid in lessening community members' anxiety regarding access to health information and technology in times of crisis. Furthermore, health sciences librarians and public librarians can collaborate in creating and delivering health information-literacy programs to the general public.

\section{Scholarship in Action}

SLIS is the only ALA-accredited degree program in the field of LIS in South Carolina. It is committed to building multi-disciplinary collaborations with other academic and research sectors and to encourage research in LIS-related areas. In the 21st century, libraries are in the process of transforming and gradually transitioning into organizations that support their users' learning activities, not just in the communities they serve, but in society as a whole. The faculty, students, and staff of SLIS are taking responsibility for producing leaders who can fully understand the mission of new librarianship, "to improve society through facilitating knowledge creation in their communities," as 
described by Lankes (2011).

Social responsibility and community impact should be central to the scholarship of information studies. LIS researchers seek not only to inform local communities, but to help shape positive changes by translating the research findings into action plans to better prepare South Carolina's libraries and librarians to meet community needs. Our knowledge inquiries have helped us better understand the value of public libraries and their services in times of crisis. The research findings bring additional insights into the value of partnerships between public libraries and public agencies, as well as public libraries and health sciences libraries, when disaster hits. Since the study was conducted in the immediate aftermath of the flooding between 2015 and 2016, it is not yet known whether there have been long-term effects on public libraries' services or on community members' ability to access information on their own. Further investigations would also be needed to see if current services provided by the public libraries in this study have changed as a result of the lessons learned from the 2015 catastrophic flooding, and if the general public feels more comfortable in using technology to access critical disaster information.

\section{References}

Di Liberto, T. (2015). Thousand-year deluge in South Carolina. Retrieved from https://www.climate.gov/news-features/event-tracker/thousand-year-deluge-south-carolina Lankes, R. D. (2011). The atlas of new librarianship. Cambridge, MA: MIT Press.

McKnight, M. (2006). Health sciences librarians' reference services during a disaster. Medical Reference Services Quarterly, 25(3), 1-12. http://doi.org/10.1300/J115v25n03 01

National Oceanic and Atmospheric Admiration. (2018). Historical hurricane track. Retrieved from https://coast.noaa.gov/hurricanes/

Orangeburg County Library System. (2019). Orangeburg County Library. Retrieved from Journal of New Librarianship, 4(2019) pp. 405-416 10.21173/newlibs/7/12 


\section{https://www.orangeburgcounty.org/ocl/}

Richland Library. (2019). Richland Library. Retrieved from https://www.richlandlibrary.com/

South Carolina Emergency Management Division. (n.d.) October 2015 statewide flooding incident. Retrieved from https://www.scemd.org/news/october-2015-flooding-incident/

South Carolina State Library. (n.d.). South Carolina State Library. Retrieved from http://www.statelibrary.sc.gov/

Stapf, J. (2015, October 5). Inside FEMA's South Carolina flooding response. Retrieved from https://www.fema.gov/blog/2015-10-05/inside-femas-south-carolina-flooding-response

Tanner, A., Friedman, D. B., Koskan, A., \& Barr, D. (2009). Disaster communication on the internet: A focus on mobilizing information. Journal of Health Communication, 14(8), 741-755. http://doi.org/10.1080/10810730903295542

Tu-Keefner, F. (2016). The value of public libraries during a major flooding: How digital resources can enhance health and disaster preparedness in local communities. In Maeda, A., \& Morishima, A. (Eds.), Proceedings of the $18^{\text {th }}$ International Conference in Asia-Pacific Digital Libraries (pp. 1015). Tsukuba, Ibaraki, Japan: University of Tsukuba.

Tu-Keefner, F., Liu, J., Harnett, E., \& Hastings, S. K. (2017). Health information services and technology access during and after a disaster: Lessons learned by public librarians in South Carolina. Journal of Consumer Health on the Internet, 21, 26-39. http://doi.org/10.1080/15398285.2017.1279895 